\title{
HOW DO THEIR "GROUP WORK" WORKS AS AN ACTIVE LEARNING STRATEGY OF EFL LEARNING
}

\author{
Sajidin ${ }^{1 *}$, Ashadi $^{2}$ \\ ${ }^{1}$ UIN Sunan Gunung Djati Bandung, Indonesia \\ ${ }^{2}$ Universitas Negeri Yogyakarta, Indonesia \\ *e-mail: sajidin@uinsgd.ac.id
}

\begin{abstract}
The implementation of active learning in junior high schools, particularly on how students respond to it is interesting to examine. The active learning program is extensively implemented in randomly selected seven provinces, at state schools in Indonesia. This research aims to investigate the implementation of EFL (English as a Foreign Language) active learning in classroom settings and to identify how the implementation is perceived by the students. To examine the implementation, 12 classroom observations at 8 purposely selected schools were carried out. Meanwhile, to identify how the implementation was perceived by the students, a number of students were interviewed, and 12 field notes were confirmed for validation. After the data were intensively analyzed, it was found that (1) active learning was evident in most classrooms in which group work was selected as the main learning strategy; (2) strategies were employed to perform different tasks and activities within ELT (English Language Teaching) sequences; and (3) most students positively responded the implementation of active learning with some suggestion for better implementation. This research recommends that the active learning approach be implemented in EFL classrooms since it potentially promotes skills other than English language skills.
\end{abstract}

Keywords: active learning, EFL, Indonesian context, junior high schools.

\section{BAGAIMANA "GROUP WORK" COCOK SEBAGAI STRATEGI PEMBELAJARAN AKTIF PADA KELAS BAHASA INGGRIS}

\begin{abstract}
Abstrak: Pelaksanaan pembelajaran aktif di Sekolah Menengah Pertama, terutama bagaimana siswa menyikapi hal tersebut menarik untuk dikaji. Program tersebut diterapkan secara ekstensif di tujuh provinsi yang dipilih secara acak, di sekolah negeri di Indonesia. Tujuan penelitian ini untuk mengungkap pelaksanaan belajar aktif di kelas-kelas bahasa Inggris dan mengetahui pendapat siswa terhadap pelaksanaan tersebut. Untuk mengungkap pelaksanaan program tersebut dilakukan pengamatan sebanyak 12 kali di 8 sekolah yang dijadikan sebagai sampel. Selanjutnya untuk mengetahui sikap siswa terhadap program tersebut sebanyak sejumlah siswa diwawancarai, dan 12 catatan lapangan dikonfirmasi untuk validasi. Setelah menganalisis data secara intensif, beberapa temuan diperoleh: (1) pembelajaran aktif terlihat di sebagian besar kelas di mana kerja kelompok dipilih sebagai strategi pembelajaran utama; (2) strategi digunakan untuk melakukan tugas dan aktivitas yang berbeda dengan mengikuti urutan-urutan pengajaran bahasa Inggris; dan (3) sebagian besar siswa menyikapinya secara positif dengan beberapa catatan untuk perbaikan. Penelitian ini merekomendasikan agar pembelajaran aktif dapat diterapkan dalam pembelajaran bahasa Inggris karena berpeluang untuk meningkatkan keterampilan selain keterampilan bahasa Inggris yang menjadi tujuan utama pembelajaran.
\end{abstract}

Kata Kunci: pembelajaran aktif, bahasa Inggris, konteks Indonesia, Sekolah Menengah Pertama.

\section{INTRODUCTION}

Active learning is commonly associated with student-centered approach (Nouri, 2016; Taraban, Box, Myers, Pollard \& Bowen, 2007; Tomkin, Beilstein, Morphew, \& Herman, 2019), cooperative learning (Harizaj, 2015; O'Neal \& Pinder-Grover, 2005), experiential learning, and learning-by-doing (Dewey, 1938). These learning approaches and strategies are closely intertwined, and are inseparable from active learning.

Within framework of student-centered approach, the students serve as subject rather than object of teaching. They take a greater space 
in classroom sessions, and the teacher mostly plays a supervisor (Harizaj, 2015). In addition, the exploration on active learning strategies will rest in the types of cooperative learning, in which student participation and activeness are of most significance. It is believed that cooperative learning can encourage the students to get engaged with learning tasks, actively participate in sharing, discussing, and collaborating with their peers (Slavin, Hurley, \& Chamberlain, 2003). Moreover, experience learning, coined by David A. Kolb, is considered an appropriate learning approach that give more rooms for students to acquire skills by experiencing (Kolb, Boyatzis, \& Mainemelis, 2014). Learning-bydoing, based on Dewey's Progressive Education, is another label, and, therefore, identical with active learning since through carrying out an activity (doing); a student becomes active, and employs his physical, as well as, mental attributes.

As opposed to passive learning, active learning approach bases its theory on Dewey's progressive education, Banduras' social learning theory, and Vygotsky's activity learning theory. John Dewey argued that education in order to accomplish its ends both for the individual learner and for society must be based upon experience-which is always the actual lifeexperience of some individuals (Dewey, 1938). Meanwhile, Bandura (1977) argues that new patterns of behavior can be acquired through direct experience of by observing others. According to Vygotsky, Davydovm, \& Robert (1977: 74), "The educational process an active one on three levels: the student is active, the teacher is active, and the environment created between them is an active one."

Students' activeness in active learning is dynamic in nature. It may range from a simply listening to teacher "explanation to collaboratively execute the presented task and perform group presentation. In a more technical term, it is a continuum: from a simple task to complex task, from acquisition of knowledge to acquisition of skills/attitudes; and, from limited interaction to extensive interaction (Bonwell \& Eison, 1991; O’Neal \& Pinder-Grover, 2005).

Referring to the learning theories above, active learning approach can be further formulated as follows: (1) students are central in learning; (2) group work and discussion are main strategies for teaching; (3) the students engage in experiencing (doing), rather than, listening and seeing and (4) more spaces are given to the students for learning by doing and experiencing, (5) a teacher mostly plays as supervisor or facilitator of learning, (6) involving instructional media and tools in teaching, and (7) student talk is more predominating than teacher talk.

Active learning is believed to contribute to student learning. It helps students develop their personal skills, as well as, social skills (Braxton, Jones, Hirschy \& Hartley, 2008; Coorey, 2016; Taraban et al., 2007), enhance students' motivation and participation (Harizaj, 2015), and promote critical thinking (Banerjee, Murthy \& Iyer, 2015; Cadima, Barros, Ferreira, Serra-Lemos, Leal \& Verschueren, 2018; Wu, Marek, \& Chen, 2013). In addition to this, active learning facilitates students to improve their academic achievement (Slavin et al., 2003; Taraban et al., 2007). The effect of active learning on students' life is everlasting since it helps students acquire skills, in addition to knowledge. Both of them are simultaneously acquired in a meaningful activity. Knowledge is constructed during their interaction with peers, as wells, their teachers. Liu \& Mathews (2005: 387) assert that knowledge is, “... actively constructed within the constraints and offerings of the learning environment." Meanwhile, skills are acquired when they engage in activities as a nurturing effect of selected active learning strategies. It is particularly true that knowledge is also acquired through their interaction with learning exposures (news, information, text, images, etc.).

Research, as well as, opinion papers on active learning is well documented in Indonesian publication. It can be traced from several scholarly articles dating back in 1980s (see, for example, Ngadiran, 1980; Arikunto, 1985). More research reports on the implementation of active learning in Indonesian schools were made in 2000s, in line with the promotion of PAIKEM (active, interactive, creative, affective learning), followed with Contextual Teaching and Learning (see, Gafur, 2003), Scientific Approach, and Character Education (Samal, 2018). Fahmi (2013), for example, employed group work strategies and the use of instructional media within context of PAIKEM. Fuadi, Johar, \& Munzir (2016) applied a discussion technique in responding teacher questions. Within sequences 
of Scientific Approach, the students are given more space to observe, to ask, and work in team (Suswandari, Siswandari, Sunardi, \& Gunarhadi, 2020), and engage in problem-based learning (Issufiah, Sunardi, Sri, \& Gunarhadi, 2018).

Most research on active learning employed quantitative approach with experimental study. Only a few research employs qualitative approach (see, for example, Daouk, Bahous, \& Bacha, 2016; Momani, Asiri, \& Alatawi, 2016). Of the previous research reports, there is no specific research qualitatively exploring the implementation of active learning in -more- thanone- schools/colleges and eliciting the students' opinion the implementation of active learning in EFL classroom settings. For example, Mulatu \& Bezabih (2018) explore the implementation of active learning in the context of Ethiopian Schools, in which the teachers become the main respondents. Daouk et al. (2016) explore students' and instructors' perceptions regarding the effectiveness of implementing active learning strategies in higher education courses conducted at a tertiary institution in Lebanon. Er \& Ataç (2014) surveys the students' attitude to the implementation of cooperative learning in the context of Turkish college students. Momani et al. (2016) investigate the teachers' views on using active learning strategies in Arabian Intermediate Schools.

Additionally, Gholam, Attaran, \& Moghaddam (2014) review all accepted paper on active learning in the context of Iranian colleges. The present research is different from the research reports above. It examines the implementation of active learning in English as Foreign Language (EFL) classrooms within the context of Indonesian Junior Secondary Schools. The research specifically focuses on the implementation of active learning at the schools and how it is responded by the students. Therefore, the research has the main goal: exploring the implementation of active learning at the schools, and identifying the students' response towards the implementation of active learning at the schools.

The present research may contribute to the better implementation of active learning in the context of Indonesian schools and, theoretically, enrich the existing research repertoires on active learning approach in ELT.

\section{METHOD \\ Research Design}

This multi- case study was carried out in Junior Secondary Schools. Eight Junior Secondary schools in the second cohort of pilot project were purposively sampled for the study. These schools, as well as other state-selected schools, give an easy access and a room for the exploration. The second cohort was taken as sample since the students' impression and experiences with the program remain easy for the elicitation.

\section{Participants}

The research involved 81 students from 8 Junior Secondary Schools in Central Java: 4 schools are under supervision of Indonesian Ministry of Religious Affair, popularly called MTsN; and the other four are under the auspices of Indonesian Ministry of Education and Culture, commonly named SMPN. From both MTsN and SMPN, students were selected as sample. By employing a convenient random sampling method, the participants were selected on the basis on the criteria set up by the researcher, that is - the participants who could articulate their experiences and they feel convenient to be interviewed. The data of the participants is presented in Table 1.

\section{Table 1. Research Participants}

\begin{tabular}{llcc}
\hline $\begin{array}{c}\text { Names of Junior } \\
\text { No Secondary School } \\
\text { (Pseudonym) }\end{array}$ & $\begin{array}{c}\text { Number of } \\
\text { Participants }\end{array}$ & Grade \\
\hline 1 & MTsN Bondowoso & 23 & 9 \\
2 & SMPN Kalijaga & 22 & 9 \\
3 & MTsN Anugrah & 29 & 9 \\
4 & SMPN Harapan 1 & 23 & 7 \\
5 & MTsN Amirah & 22 & 8 \\
6 & SMPN Karangasem & 23 & 9 \\
7 & MTsN Walisongo & 25 & 7 \\
8 & SMPN Harapan 2 & 30 & 9 \\
& & \multicolumn{2}{c}{ Total: } \\
\hline
\end{tabular}

\section{Data Collection Techniques}

To explore the implementation of active learning approach in the schools understudy, 
observation in EFL classrooms was employed as main data collection technique. These -12-prolonged classroom observations were considered sufficient for gaining relevant and rich data. Teachers' and students' activities in any stages of EFL instruction as well as classroom settings were carefully recorded in 12- hand-written field notes. The field notes were adapted from Lynch's (1996) model of classroom observation, staged in every single 5-7 minutes with specific comments afterwards.

Eighty one students from eight Junior Secondary Schools participated in the interview to reveal the perception to the implementation of active learning. The interviews were tape recorded, and transcribed into verbatim data. The findings from interview were confirmed with the filed notes to match their perceptions and physical response during classroom sessions. This means the interview data were validated with field notes from the observation.

\section{Data Analysis}

Upon completing data collection, the raw data went through the following procedures: data restoration, followed with, data classification, data reduction, data display, drawing conclusion, and data verification.

The hand-writing data from classroom observations were retyped for readability. Likewise, data from interviews were transcribed for easy analysis. Both data were classified in different files: interview data and classroom observation data. Focusing on the research goals, that is - exploring the implementation of active learning at the schools, and identifying the students' response towards the implementation of active learning at the schools, both data were thoroughly analyzed for coding and, later, categorizing. The same phenomena were given the same codes and were displayed in tables for the interpretation. The conclusion was drawn after c, carefully looking the interconnection among the categories. Data verification was carried out to validate the temporary findings. For example, the temporary finding from interview was verified with the data of observation (field notes).

The research employed two types of coding for different sources of data: hierarchal coding and thematic coding. The former was employed for analyzing interview data and the latter was used for observation data, as well as, interview data. To identify the students' response to the implementation of active learning, two major categories were developed: POSITIVE and NEGATIVE. To further identify any kinds of POSITIVE responses, sub categories were developed. These sub categories were developed from codes representing the same phenomena. In addition, to identify the students' suggestions for a better implementation, and to know the perceived benefits of the implementation of active learning, as well as, to explore active learning strategies selected by the teachers, thematic coding was carried out.

\section{FINDINGS AND DISCUSSION Findings}

The findings and discussions are subdivided to follow the research aims: (1) exploring active learning strategies employed by the teachers in the schools understudy, and (2) identifying the students' perception to the implementation of active learning in the schools. The former used classroom observation as main data; meanwhile, the latter used face-to-face interviews as the main data collection techniques.

\section{The Active Learning Strategies Implemented in the Schools}

Twelve observations (Obs.) conducted to the eight - selected schools reveal that active learning was implemented in most EFL classrooms with different degree of students' engagement. It rangers from simple cognitivemental activities, such as individually listening teachers' instruction and explanation, identifying and analyzing tasks to more complex behavior -physical activities, such as, collaboratively execute the presented tasks and perfume group presentation. The type of students' activity is structured in active learning strategies selected by the teachers from one school to another.

\section{Group Work}

It is evident in most classroom observations. Of 12 observations, there were 11 times of group work employed in the classroom. Group work was selected to employ different tasks and activities. As demonstrated in the Table 2 , these activities were collaboratively done in a group work. 
Table 2. Group work

\begin{tabular}{lll}
\hline Students' Activities & $\begin{array}{l}\text { Time Range } \\
\text { (in every } 5 \text { minutes) }\end{array}$ & Obs. \# \\
\hline 1. Describing people & $9^{\text {th }} 5 \mathrm{~min}$. & $\# 01$ \\
2. Writing a recount text & $13^{\text {th }} 5 \mathrm{~min}$. & $\# 03$ \\
3. Writing narrative text & 3 th $5 \mathrm{~min}$. & $\# 04$ \\
4. Describing animal pictures & $8^{\text {th }} 5 \mathrm{~min}$. & $\# 05$ \\
5. Putting the picture into order. & $4^{\text {th }} 5 \mathrm{~min}$. & $\# 06$ \\
6. Filling in the table & $6^{\text {th }} 5 \mathrm{~min}$. & $\# 07$ \\
7. Writing a descriptive text. & $5^{\text {th }} 5 \mathrm{~min}$. & $\# 10$ \\
8. Putting pictures in order. & $5^{\text {th }} 5 \mathrm{~min}$. & $\# 11$ \\
9. Finding Indonesian corresponding & $5^{\text {th }} 5 \mathrm{~min}$. & \\
\hline
\end{tabular}

A group work was chosen to execute different types of tasks and activities. The label was given since the activities began with discussion of the task, and, followed with the execution of the tasks. All the tasks were done in group in which all participants sat in opposing positions for easy communication. Within a group there was a leader appointed by its members or by the teacher. The leader was responsible for the task completion in the respective group.

\section{Group Presentation}

Group presentation was mostly carried out upon completing a group work. As the name suggests, it is selected to present the students' works or projects (see Table 3). The strategies were found in six classroom observations: obs. $\# 03$, obs. \#04, obs. \#05, obs. \#06 obs. \#07, and obs. \#10. It was selected to present the students' works after group work activities.

Group presentation was led by a leader playing as a moderator and was assisted by his group members. The projects were put on the wall or held by his two or three group members. Then, a speaker/presenter read, or explained his ideas from the presented project.

\section{Pair Works}

Pair works, meaning two people working in pairs, were found in three times of classroom observation: (obs. \#01, obs. \#02, and obs. $\# 12$. This strategy was recorded in three filed notes with the activities as follows: identifying adjectives in a given text, playing a role, and writing English instructions shown in Table 3.

Pair works, as seen in the Table 3, are conducted in $1^{\text {st }}$ to $4^{\text {th }} 5$ minutes. This suggests that the strategies are employed in the phase of pre teaching activities. It may serve as an ice breaking to draw the student's attention and to make every student active since the beginning of the teaching sessions.

\section{Self-reflection}

By self-reflection, it means asking the students to jot down, in a piece of paper, their opinions dealing with the learning activities developed by their teachers. The strategy was evident in three classroom observations: Obs. $\# 05$, Obs. \#10, and Obs. \#11. The activities were commonly followed with the collection of the papers, and put them on the flashcard. The positive impressions are put on the left side of the cardboard and the negative ones are put on the left side, or vice versa shown Table 3 .

Self-reflection, as demonstrated in the Table 3, is employed in the middle or in the last phase of teaching. It is a sort of post teaching activities that serves as a feedback for a teacher from which he can take a lesson for the betterment of his teachings.

\section{Ice Breaking}

Ice breaking was found in two times of classroom observation. It serves to make students ready for learning by presenting a game or fun activities. The students were active in calling their parts of body and following teacher's instructions shown in Table 3.

Ice breaking is presented, as the Table 3 suggests, in the pre teaching activities. Pre teaching activities are all about language preparation and warming-up prior to task execution. 
Table 3. Activities After Group Work

\begin{tabular}{llll}
\hline Stage & Students' Activities & $\begin{array}{l}\text { Time Range } \\
\text { (in every 5 minutes) }\end{array}$ & Obs. \# \\
\hline Group & 1. Presenting a fill - in form in group & $3^{\text {td }} 5 \mathrm{~min}$. & $\# 03$ \\
presentation & 2. Identifying regulars' verbs & $10^{\text {th }} 5 \mathrm{~min}$ & $\# 04$ \\
& 3. Presenting group's project. & $16^{\text {th }} 5 \mathrm{~min}$. & $\# 05$ \\
& 4. Presenting group's project & $10^{\text {th }} 5 \mathrm{~min}$. & $\# 06$ \\
& 5. Presenting group's project & $14^{\text {th }} 5 \mathrm{~min}$ & $\# 07$ \\
Pair works & 6. Presenting group's project & $15^{\text {th }} 5 \mathrm{~min}$. & $\# 10$ \\
& 1. Identifying adjectives in a given text & $2^{\text {nd }} 5 \mathrm{~min}$. & $\# 01$ \\
& 2. Playing a assigned role & $1^{\text {st }} 5 \mathrm{~min}$. & $\# 02$ \\
Self-reflection & 3. Writing English instructions & $4^{\text {th }} 5 \mathrm{~min}$. & $\# 12$ \\
& 1. Writing students 'personal learning reflection & $26^{\text {th }} 5 \mathrm{~min}$. & $\# 05$ \\
Ice breaking & 2. Writing their impressions & $16^{\text {th }} 5 \mathrm{~min}$. & $\# 10$ \\
& 3. Assessing student project. & $9^{\text {th }} 5 \mathrm{~min}$. & $\# 11$ \\
Brainstorming & 1. Mentioning part of body & $1^{\text {st }} 5 \mathrm{~min}$. & $\# 08$ \\
& 2. Simon says & $2^{\text {nd }} 5 \mathrm{~min}$. & $\# 08$ \\
Role playing & 1. Asking students' activity in the past & $1^{\text {st }} 5 \mathrm{~min}$. & $\# 03$ \\
& 2. Reviewing students' vocabulary mastery & $1^{\text {st }} 5 \mathrm{~min}$. & $\# 08$ \\
& 1. Playing a role in given dialogue & $1^{\text {st }} 5 \mathrm{~min}$. & $\# 02$ \\
\hline
\end{tabular}

\section{Brainstorming}

Brainstorming was found in two field notes, meaning there were two brainstorming activities presented in the classroom. It is aimed at eliciting students' opinion. There is no wrong or right answer. The most important one is that there are a plenty of oral response from the students shown in Table 3.

Like ice breaking activities, brainstorming was carried out in the beginning of the teaching. This made students active since the first phase of their learning. As presented in the Table 3, the strategy was employed at the first five minutes.

\section{Role Playing}

Role playing was the only strategy during classroom observations. It was found in obs. \#02 when the students were playing as a father and a mother. The strategy began with distribution of a written dialogue (Table 3), which was followed with playing their role. Since the strategy was carried out in the beginning of the classroom sessions, it serves as a warming up activity. An analysis on the field note reveals that after conduction a role playing, they continued learning with a different topic of presentation.

From the Table 2 and 3, it can be implied that group work is the most frequently selected strategy in the classrooms. It is followed with group presentation, pair woks, self-reflection, ice breaking, brainstorming, and role playing.

In fact, several active learning strategies are employed in one classroom session. For example, in addition to group work, the teachers employed classroom presentation, and self- reflection. It is evident in 10 of 12 classroom observations in which the teachers selected two or more active learning activities in one classroom session. In this case, ice breaking, group work, classroom presentation, and self- reflection strategies were applied in one classroom meeting. Therefore it is safe to say that a complete active learning model implemented the schools shown in Figure 1.
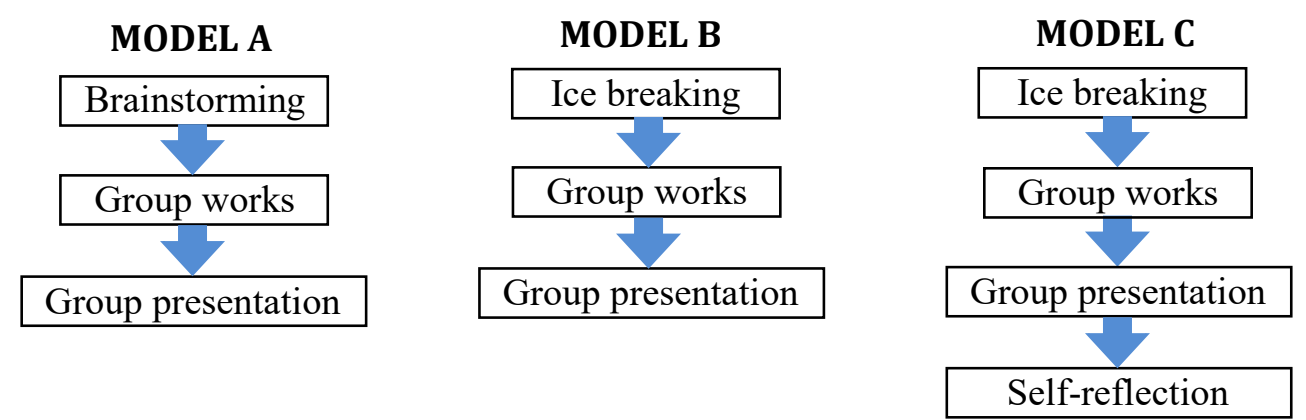

Figure 1. The Patterns of Active Learning 
Model A is formulated in the classroom observations: \#03; meanwhile, model B is found in the classroom observation: \#04 and \#07 Model C, the most holistic pattern, is evident in the classroom observation: \#11. The strategies were designed by a teacher at MTsN Bondowoso which was completed within 70 minutes of teaching. How the model emerges can be seen in Figure 2.

The classroom activity begins with the building of group (10.20). It is then followed with the icebreaking. In this case, the teacher shows a picture of Koala bear, and asks what the picture is about. Group work begins when the teacher distributes a worksheet to do in group (10.27), and ends when it has been filled in by one of the groups (10.48). It means group work takes place in 21 minutes. The participants of the group work come forward to present their work (10.55). So, the group presentation is carried out between 10.55- 11.16. Self- assessment or self -reflection is conducted after all learning sessions are done (11.16). It takes place within 14 minutes.

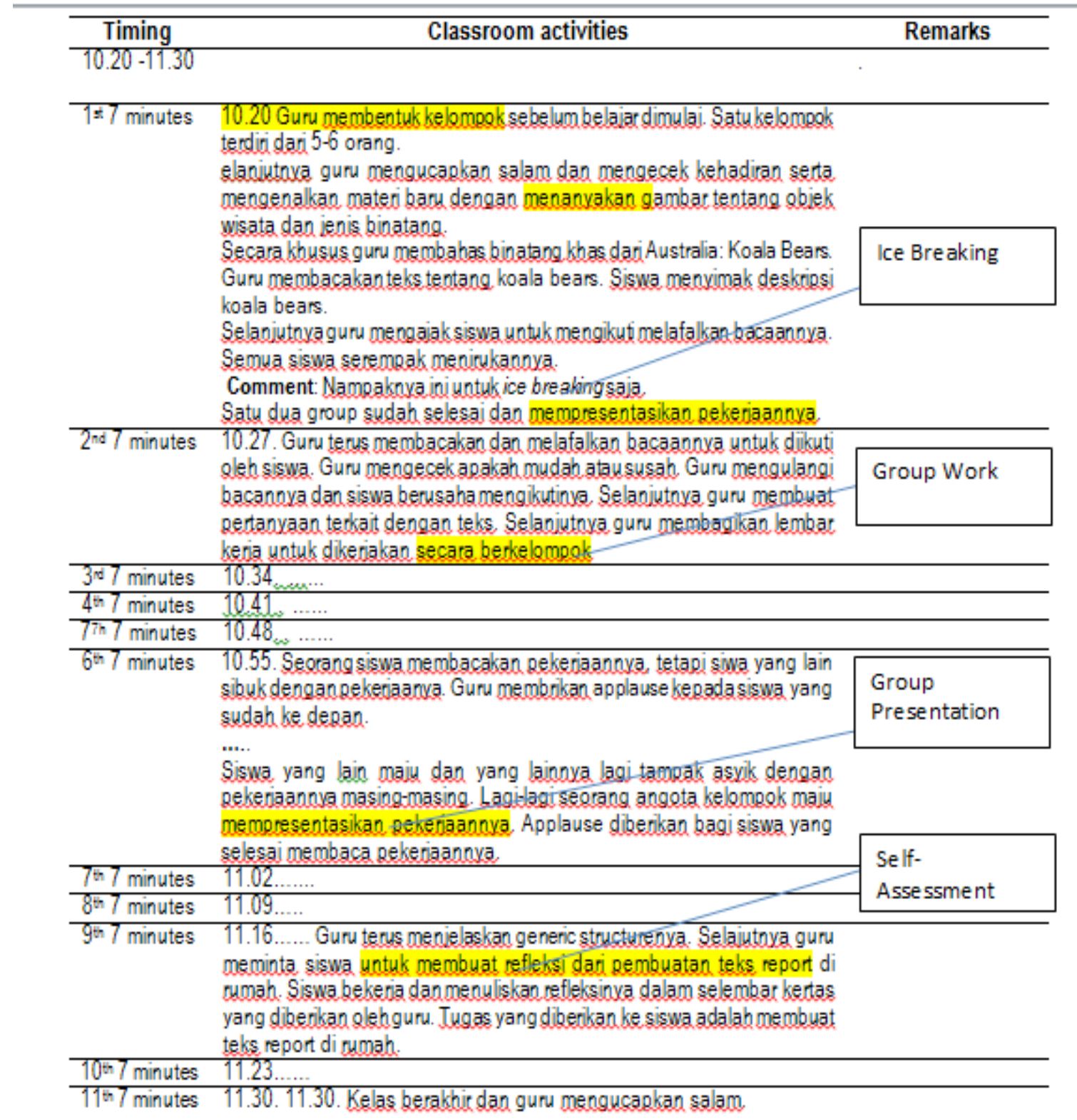

Figure 2. Example of Thematic Analysis of The Classroom Activities with the Emerging Model 
The Students' Perception towards the Implementation of Active Learning

This part is subdivided into three major issues: their impression with presented instruction, their experience with selected strategies, and weaknesses of active learning and the students' suggestions for better implementation.

\section{The Students' Impression with the Presented Instruction}

Most respondents give a specific answer with the most frequent words, senang (excited) or menyenangkan (exciting). The former comes with 21 responses $(77.78 \%)$; meanwhile, the latter was stated by 6 respondents $(2.22 \%)$. It means that the students feel excited with the active learning approach. In other words, the active learning approach practiced in the school is exciting the students.

It means that all students have a positive response to the implementation of active learning in their respective schools. In other words, the active learning approach practiced in the school is exciting the students. A negative response was put forward by one respondent at the beginning of implementation but it grew positive after several meetings.

Drawing from al the responses above, it is obvious that teaching strategies selected by the teachers and implemented by the schools give a positive impression to the students. Such a positive impression was supported by their reasons. The students can collaboratively work with their peers (R\#02, R\#04, R\#12, R\#12, $\mathrm{R} \# 18, \mathrm{R} \# 19$, and $\mathrm{R} \# 24)$; express their opinions deliberately (R\#01, R\#03, R\#09, R\#10, R\#11); learn from others (R\#10; $R \# 14, \mathrm{R} \# 17$; R\#23, and $\mathrm{R} \# 25$,); and learn better (R\#13, as well as, enjoyable (R\#13).

\section{The Perceived Benefit Gained after Attending Active Learning}

Active learning was perceived to contribute to several aspects of the students 'life: (1) social skills (52\%), (2) effective learning (16\%) and intrapersonal skills (8\%). Social skills are indicated by their ability to: (a) to work together (R\#04, R\#06, R\#09, R\#\#10, $\mathrm{R} \# 13$, R\#16，R\#19，R\#19，R\#23，and R\#25; (b) to expresses his ideas (R\#01, R\#04, R\#07, $\mathrm{R} \# 11, \mathrm{R} \# 21$, and $\mathrm{R} \# 25$ ); and (c) to listen to others (R\#13). Intrapersonal skills are indicated with self -awareness (R\#09); and control over himself (R\#01). Furthermore, by effective learning, it means learning get facilitated so it helps students learn better. It is expressed by 4 respondents (R\#14, R17, R\#22, and R\#25). Six selected statements elicited from the respondents may represent the types of benefits gained after attending active learning approach.

The students' social skills may grow since most of the time, the students are given a lot of space to work to gather, to express their idea, and to listen to others in a group work. Similarly, by engaging in a group work, the students become aware of their ability and can control themselves from talking while other people talk. At the same time, by a group work, the students can learn from others and collaboratively solve the problem.

\section{Weaknesses of Active Learning and the Students' Suggestions for a Better Implementation}

Despite their positive responses, the implementation of active learning at the schools needs to be made batter in terms of the following aspects: (1) classroom management, (2) frequency of group work, and (3) teachers' voice.

Classroom management has the following weaknesses and, therefore, needs to be improved: (a) a lot of noise, (b) lack of control, (c) inaudible instruction, (d) students' reluctance, and (e) the big number of group work participants. Noise comes from the students who were having a chat during teachers while the teacher was giving an instruction (R\#20 and R\#26). The teachers have a lack of control/supervision ( $\mathrm{R} \# 10$ and $\mathrm{R} \# 12$ ). The teachers' voice is inaudible (R\#05). Some students are reluctant to work in group ( $\mathrm{R} \# 18)$; and (e) there are too many participants in one group (R\#27).

The analysis on the field notes (obs. \#03:09.07) proves that the students did not pay any attention to the teacher' explanation (09.07). It may happen due to the siting arrangement; some students cannot directly see the teachers. They also tend to talk to themselves, rather than to listen to the teacher explanation (obs. \#05: 09.18). Teachers' low voice and elaborate instruction are assumed as its main factors why this comes to happen.

With several weaknesses of active 
learning the students experienced, they bring with some ideas to cope with them. The following suggestions were posted to reduce the weaknesses of active learning implemented in the schools. Dealing the frequency of group work, some students suggested that group work be employed once in a while (R\#02 and

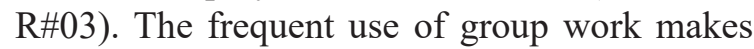
the teaching content hard to complete within the allotted time.

\section{Discussion}

\section{The Active Learning Strategies Implemented in the Schools}

The schools have implemented active learning by selecting number of active learning strategies as frequently mentioned, and recommended by some scholars: group work, including group discussion (Bonwell \& Eison, 1991; Mulatu \& Bezabih, 2018; Momani et al., 2016), role playing (O’Neal \& Pinder-Grover, 2005; Mulatu \& Bezabih, 2018), brainstorming (O'Neal \& Pinder-Grover, 2005; Momani et al., 2016), pair work (Bonwell \& Eison, 1991; Daouk et al., 2016;), group presentation (Bonwell \& Eison, 1991) self-assessment, including selfreflection (O'Neal \& Pinder-Grover, 2005; Momani et al., 2016). The strategies mentioned above fit with active learning approach in which students are involved in more than passive listening, engaged in activities (Bonwell \& Eison, 1991). In the context of ELT, the criteria of active learning is even more flexible. When a teacher asks his students to practice listening (including reading, and writing), he implements an active learning approach (see Momani et al., 2016).

\section{Group Work}

Group work, including group discussion, has been the most frequently selected strategy in the implementation of active learning approach. The strategy provides students with a greater opportunity to participate in discussing, team work, peer learning, collaborative and cooperative learning. This social context of learning is given more emphasis in active learning (Drew \& Mackie, 2011). Therefore, group work is identical with active learning, and is oftentimes found to be inseparable from it. Within a continuum of active learning, group work belongs to a simpler task (O'Neal \&
Pinder-Grover, 2005) The strategy is believed to promote interpersonal skills among group members (Galton, 2010), and help hold human relationship (Drew \& Mackie, 2011).

\section{Group Presentation}

Group presentation, as well as, individual presentation, is classified as a high risk active learning strategy (Bonwell \& Eison, 1991). By high risk, it means group presentation makes the students less comfortablein their learning. Parallel to this, Barry (2012) states that group (oral) presentation is the most daunting experience a student will undertake. It is also found that group presentation is not considered an interesting and stimulating way to work with group member (Chou, 2011). However, it is widely understood that a successful presentation generates a self confidence among group members. Therefore, it is also the most rewarding activity in another side. Group presentation is a common part of many students' university experience that may be found beneficial to be experienced since early as preparation for further academic life as well as future career.

\section{Pair Work}

Pair work, is frequently classified as another type of group works in which two or more people work together to achieve a particular learning goal or to complete an assigned task. O'Neal \& Pinder-Grover (2005) put pairwork on active learning strategy continium which approaches simple task activity, in the form of think-pair-share. It urges students to be reflective about course content (Hermann, 2013, in Daouk et al., 2016). Within the context of ELT, pair work is commonly practiced in performing a dialogue between two people, or administrating an interview simulation or role playing. Both of them make students active in posting questions, listening and responding them.

\section{Self-Reflection/Assessment}

Self -refection is an active learning strategies advocated by some scholars (see, for example, O'Neal \& Pinder-Grover, 2005; Momani et al., 2016). The students conducting a self-reflection is mentally active in thinking, analyzing, and learning from their experience (Hilloran, 2016). These activities are inherent in self-reflection and are relevant to the core 
concept of active learning. Shen \& Xu (2015, 82) put forward that "The core concept of active learning involves engaging students not only in actively exploring knowledge but also in reflecting on their own learning process in order to become more effective learners". Selfreflection is mostly likely to be carried out at the end of classroom sessions in which a learning experience becomes points to reflect.

\section{Ice Breaking}

Ice breaking is an active learning strategy that encourages students to listen to the teachers' instruction, and to take an action afterwards. It is commonly used in the beginning of classroom sessions, or beginning of the workshop (Almethhib, 2009). Kilannowski (2012) argues that ice breaking can help participants to bond, form a new team, get to know people from different backgrounds, and become involved with learning about new subject matter. Besides, it helps the leader become acquainted with the participants and with interpersonal interactions in the group. Almethhib (2009) suggests that any training workshop of one full day or more should have an "ice breaking" session of approximately 50 minutes. This implies that ice breaking should be limited not to take more than 10 minutes in each classroom session, assuming that one- fullday training takes 8 hours long.

\section{Brainstorming}

Brainstorming is one of active learning strategies suggested by O'Neal \& PinderGrover (2005). It belongs to middle continum in between simple task and complex task active learning catagories. By employing brainstorming technique, students are active to share their thoughts and ideas (Al-Samarraie \& Hurmuzan, 2018) and to ask questions "That evoke their interest and natural curiosity" (Unin \& Bearing, 2016: 607). The technique is often used to begin with reading class to activate students' prior knowledge. Otherwise, it is used in writing class to generate their ideas and document them by using sketches or words from which they develop their ideas into writing project.

\section{Role Playing}

Role playing makes the students active from the beginning of the session; reading a script, rehearsing their role, and acting it out in front of audiences. Within Group work, some roles are played: a leader of the group, a moderator, a presenter, and a cardboard decorator. Role playing is important to provide students an opportunity to practice the transformational leadership style (Hamdani, 2018). In addition to this, it may develop active listening and problem-solving skills, show, empathy, promote teamwork, and create effective communication (Vizeshfar, Zare, \& Keshtkaran, 2019). According to Momani et al. (2016) role plays integrate real-life stories and real-world situations. This may facilitate the students to properly use English within appropriate context.

\section{The Students, Perception towards the Implementation of Active Learning}

The discussion on this part will address three major issues above: (1) The students' impression with the presented instruction; (2) the perceived benefit gained after attending active learning, and (3) the students' suggestions for a better implementation.

\section{The Students' Impression with the Presented Instructions}

The implementation of active learning is generally responded positively by teachers. Study conducted by Mulatu \& Bezabih (2018) strengthens the assumption. It is also positively responded by most students, for example, R\#07 states, "I feel excited and the instruction doesn't make me easily bored." Similarly, R\#9 says "I feel more comfortable and have more space to express [my thoughts]." Daouk et al. (2016) report their research findings after surveying 37 education students. The research reveals that there is positive perception towards active learning strategies. The findings of the present study may temporally infer that active learning is positively responded by college students and teachers, as well as, students of junior secondary schools.

Their positive perception seems to be rooted from the different roles and responsibilities they have/play, among other things: (1) the learning benefits perceived and experienced by the students under study, and (2) learning atmosphere shared by them. Swiderski (2011), for example, identifies that active learning helps in building learners' self-esteem. The following section is going to be devoted to explore what 
benefits gained after attending active learning.

\section{The Perceived Benefit Gained after Attending Active Learning}

The finding of the present study strengthens those of the previous study that active learning is beneficial for several aspects of students' academic life, as well as, their social life. For example, an academic benefit was acquired by R\#09m stating:" [I am] able to learn better." Meanwhile, a social benefit was gained by R\#10: "Able to discus with others, to mutually help, to work collaboratively." First, and for the most, is that it helps students develop social skills. The skills are acquired from their participation and cooperation in a group work and other active learning strategies. Daouk et al. (2016: 367) state that "active learning techniques lead to increased students' participation and cooperation." Meanwhile, Coorey (2016) suggests that active learning, particularly peer learning, fosters a collaborative learning community, increases leadership skills and creates lifelong learners. Relevant to this, Baxton et al. (2008) state that class discussion, a form of active learning, positively influence social integration.

Students' academic life grows better from their effective learning activities. It is widely believed that active learning can promote a better outcome. A survey conducted by Daouk et al. (2016) report that active learning motivate students and engage them in the lesson, and develop their higher- order thinking. Additionally, active learning, particularly group wok, enables students to learn from one another (Cohen \& Lotan, 2014). They have a space to confirm their understanding to others, to get feedback from them, and to consult teacher's vague instruction with them. Compared to traditional teaching method, active learning helps students learn more, retain the information longer, and enjoy the class more (Gholami, Attaran, \& Moghaddam, 2014). Relevant to this, Braxton et al. (2008) state that student knowledge and understanding of course content benefit from the use of active learning by college and university faculty.

Dealing with intrapersonal skills, active learning can promote self-confidence and selfreliance (Momani et al., 2016), and build selfesteem (Swiderski, 2011). Again, this strengthen the finding of the present study that active learning build students' self-confidence. Their engagement in group work and oral presentation seems to contribute their acquisition of the skills. This is evidently found in one of the respondents, (R\#9): “feeling confident to express my thoughts"

Put briefly, the benefits of active learning perceived by the students and their corresponding findings from the previous research can be seen in the Table 4

Table 4. The Perceived Benefits of Active Learning

\section{No. Improved Abilities}

1. Social skills

- work together (collaboration)

- expressing ideas

- listening to others

2. Intrapersonal skills

- $\quad$ self-confidence

- $\quad$ self-awareness

- controlling over oneself

3. Promoting effective learning

- learning from their peers

- getting feedback from others
Relevant Theories and Assumptions

Coorey (2016); Daouk et al. (2016);

Braxton et al. (2008)

Momani et al., 2016); Swiderski

Daouk et al. (2016); Cohen \& Lotan

(2014); Gholami et al. (2014) 


\section{Weaknesses of Active Learning and Suggestions for a Better Implementation}

Implementing active learning approach does not always meet our expectation. Some weaknesses are frequently found, and problems are encountered by some teachers. As stated by $\mathrm{R} \# 20$, for example "the students (who) talk to themselves out of the topics presented and this makes noisy."

As put forward by the respondents and validated by the data from classroom observation, some students do not respond the teachers' instruction and they frequently talk to themselves, rather than listening to the teachers. Besides, they find that the content subjects could not be delivered within available time range. Those phenomena are common in the practices of active learning.

Bonwell \& Eison (1991: 4) states that, "You cannot cover as much course content in the time available." Lack of cooperation from participants in group work and other active learning strategies are an important issue among practitioners and, therefore, they have proposed some tips to cope with it. Forehand, Leigh, Fatrell, \& Spurlock (2015), and Davis (1993), for example, come with the same suggestion: the number of group work participants should be reduced. However, there is no an agreed-upon opinion dealing with the group size. The former suggested that the number of participants is not more than eight or nine members. Meanwhile, the latter recommends that the group size be made small with three to four members. This may promote more collaboration and shared work. Further, Forehand et al. (2015) advice that monitoring of group participation throughout the entire project process be carried out to promote an effective group work. In line with this, Fung (2014) suggests that the adults (instructors, teachers) involve to facilitate autonomous group functioning. Dealing with the second phenomena, it is suggested that students be given reading and writing assignment, examination, through their classroom examination, etc. (Bonwell \& Eison, 1991). Reading tasks assigned prior to classroom meeting seems to be important to equip them with background knowledge that may facilitate a better learning.

The respondent's suggestion to reduce the number of group members was frequently stated by the respondents. Specifically, R\#27 suggests: "the number of participants in a group work is limited to 4 people." It seems to be justified by some scholars and, therefore, is highly recommended to promote effective active learning strategies. By so doing, all members of group takes more advantages from implementing active learning.

\section{CONCLUSION}

The research brings with some important points to consider. First, the schools have implemented active learning approach by selecting active learning strategies. The strategy frequently used is group work with their accompanying activities (such as group discussion and group presentation). Group work becomes core learning activities preceded with brainstorming, ice-breaking or role playing, and is followed group presentation and selfreflection afterwards. By employing a group work, the students are engaged with their peers in listening the teachers' instruction, collaboratively understanding, then, translating it into a project work, and later presenting it in front of the class. This student- centered teaching is evident in most EFL classrooms with different degree of students 'activeness. Second, the students' responds to the teachers' selection of active learning strategies brings about a positive impact on the part of the students. It is generally claimed that the teaching help them develop their social skills, intrapersonal skills, and promote a better learning. Third, it is imperative that for an effective group work, ELT teachers limit the number of group work participants for not more than eight people. Besides, since active learning may take teachers' preparing time, a teacher should involve other teachers and collaboratively work with them in selecting materials, designing lesson plan, and preparing instructional media. The present research left two major issues unexplored: how much course content is left if active learning is implemented along the year, and: how much burden is taken by both teachers and school managers to implement active learning in their respective schools. Therefore, further research is recommended to explore the phenomena. 


\section{REFERENCES}

Al-Samarraie, H., \& Hurmuzan, S. (2018). A review of brainstorming techniques in higher education. Thinking Skills and Creativity, 27, 78-91. https://doi. org/10.1016/j.tsc.2017.12.002.

Almethhib, M. (2009). The impact of ice breaking exercises on trainees' interactions and skill acquisition: an experimental study. Journal of King Abdulaziz UniversityEconomics and Administration, 23(1), 3-20. https://www.kau.edu.sa/Files/320/ Researches/51739 21874.pdf.

Arikunto, S. (1985). Memacu pelaksanaan cara belajar siswa aktif (cbsa) melalui pelayanan supervise. [Encouraging the implementation of active student learning (CBSA) through supervision services]. Cakrawala Pendidikan, 2(2), 20-31. https://doi.org/10.21831/cp.v2i2.7414.

Bandura, A. (1977). Social learning theory. New Jersey, NJ: Prentice Hall.

Banerjee, G., Murthy, S., \& Iyer, S. (2015). Effect of active learning using program visualization in technology-constrained college classrooms. Research and Practice in Technology Enhanced Learning, 10(1), 1-25. https://doi.org/10.1186/s41039-015$\underline{0014-0}$.

Barry, S. (2012). A video recording and viewing protocol for student group presentations: Assisting self-assessment through a Wiki environment. Computers \& Education, 59(3), 855-860. https://doi.org/10.1016/j. compedu.2012.04.008.

Bonwell, C. C., \& Eison, J. A. (1991). Active learning: Creating excitement in the classroom. Washington, DC: The George Washington University. www.activelearning-site.com.

Braxton, J. M., Jones, W. A., Hirschy, A. S., \& Hartley, H. V. (2008). The role of active learning in college student persistence. New Directions for Teaching and Learning, 2008(115), 71-83. https://doi. org/10.1002/tl.326.
Cadima, J., Barros, S., Ferreira, T., SerraLemos, M., Leal, T., \& Verschueren, K. (2018). Bidirectional associations between vocabulary and self-regulation in preschool and their interplay with teacherchild closeness and autonomy support. Early Childhood Research Quarterly, 46, 75-86. https://doi.org/10.1016/j. ecresq.2018.04.004.

Chou, M.-H. (2011). The influence of learner strategies on oral presentations: A comparison between group and individual performance. English for Specific Purposes, 30(4), 272-285. https://doi. org/10.1016/j.esp.2011.04.003.

Cohen, E. G., \& Lotan, R. A. (2014). Designing groupwork strategies for the heterogeneous classroom. New York, NY: Teachers College Book

Coorey, J. (2016). Active learning methods and technology: Strategies for design education. International Journal of Art and Design Education, 35(3), 337-347. https://doi.org/10.1111/jade.12112.

Daouk, Z., Bahous, R., \& Bacha, N. N. (2016). Perceptions on the effectiveness of active learning strategies. Journal of Applied Research in Higher Education, 8(3), 360-375. https://doi.org/10.1108/ JARHE-05-2015-0037.

Davis, B. G. (1993). Collaborative learning: Group work and study teams. In B. G. Davis (Ed.). Tools for teaching. San Francisco, CA: Jossey-Bass, pp 147-152.

Dewey, J. (1938). Experience and education. New York, N.Y: Touchstone.

Er, S. \& Ataç, A. B. (2014). Cooperative learning in ELT classes: The attitudes of students towards cooperative learning in ELT classes. International Online Journal of Education and Teaching (IOJET), 2(1), 109-122. https://www.iojet.org/index. php/IOJET/article/view/28.

Forehand, J. W., Leigh, K. H., Fatrell, R.-G., \& Spurlock, A. Y. (2015). Social dynamics in group work. Teaching and Learning 
in Nursing, 11(2), 62-66. https://doi. org/10.1016/j.teln.2015.12.007.

Fuadi, R., Johar, R., \& Munzir, S. (2016). Peningkatkan kemampuan pemahaman dan penalaran matematis melalui pendekatan kontekstual. [Improve mathematical understanding and reasoning skills through a contextual approach]. Jurnal Didaktika Matematika, 3(1), 47-54. http://www.jurnal.unsyiah. ac.id/DM/article/view/4305.

Fung, D. (2014). Promoting critical thinking through effective group work: A teaching intervention for Hong Kong primary school students. International Journal of Educational Research, 66, 45-62. https:// doi.org/10.1016/j.ijer.2014.02.002.

Gafur, A. (2003). Penerapan konsep dan prinsip pembelajaran kontekstual (contextual teaching and learning) dan desain pesan dalam pengembangan pembelajaran dan bahan ajar. [Application of contextual teaching and learning concepts and principles and message design in the development of learning and teaching materials]. Cakrawala Pendidikan, 3(22), 273-289. https://journal.uny.ac.id/index. $\mathrm{php} / \mathrm{cp} /$ article/view/7419.

Galton,M. (2010). Assessing group work. In P. Peterson, E. Baker, \& B. McGaw (Eds.). International encyclopedia of education (3rd ed). Cambridge, UK: Elsevier, pp. 342-347. https://doi.org/10.1016/B978-008-044894-7.00356-0.

Gholami, V., Attaran, A., \& Moghaddam, M. M. (2014). Towards an interactive EFL class: Using active learning strategies. Research on Humanities and Social Sciences, 4(19), 190-195. https://iiste.org/Journals/index. php/RHSS/article/view/15780.

Hamdani, M. R. (2018). Learning how to be a transformational leader through a skillbuilding, role-play exercise. International Journal of Management Education, 16(1), 26-36. https://doi.org/10.1016/j. ijme.2017.11.003.
Harizaj, M. (2015). Discussion as an active learning in EFL. European Scientific Journal, 11(16), 231-236. https:// eujournal.org/index.php/esj/article/ view/5866.

Hilloran, L. (2016). The value of self-reflection. The Journal for Nurse Practitioners, 12(10), E437-E438. https://doi. org/10.1016/j.nurpra.2016.09.004.

Issufiah, D. N., Sunardi, S., Sri, A. W., \& Gunarhadi, G. (2018). The implementation off problem based learning model (PBL) on teachers and students grade five elementary schools in Surakarta. International Journal of Active Learning, 3(2), 116-123. http://journal.unnes.ac.id/ nju/index.php/ijal/article/view/13411.

Kilannowski, J. F. (2012). Breaking the ice: a preintervention strategy to engage research participants. Journal of Pediatric Health Care, 26(3), 209-212. https://doi. org/10.1016/j.pedhc.2012.01.001.

Kolb, D. A., Boyatzis, R. E., \& Mainemelis, C. (2014). Experiential learning theory: Previous research and new directions. In R. J. Stenberg \& L-F Zhang (Eds.). Perspectives on Thinking, Learning, and Cognitive Styles. Mahwah, NJ: Lawrence Erlbaum Associates, pp. 227-247. https:// doi.org/10.4324/9781410605986-9.

Liu, C. H., \& Matthews, R. (2005). Vygotsky's philosophy: Constructivism and its criticisms examined. International Education Journal, 6(3), 386-399. https:// openjournals.library.sydney.edu.au/index. php/IEJ/article/view/6796/7436.

Lynch, B. K. (1996). Language program evaluation: Theory and practice. New York, NY: Cambridge University Press.

Momani, M., Asiri, A., \& Alatawi, S. M. (2016). The impact of implementing active learning strategies in teaching English from the perspective of tabuk educational region intermediate school teachers. Asian Journal of Educational Research, 4(1), 19-35. www.multidisciplinaryjournals. com. 
Mulatu, M., \& Bezabih, W. (2018). Perceptions and practices of EFL teachers in implementing active learning in English classes: The case of three selected secondary schools in Dawro Zone, Snnprs, Ethiopia. International Journal of Education, 10(2), 88-94. https://doi. org/10.17509/ije.v10i2.8461.

Ngadiran, N. (1980). Kerja kelompok sebagai strategi/metode belajar mengajar. [Group work as a teaching and learning strategy/ method]. Cakrawala Pendidikan, 1(1), 22-35. https://journal.uny.ac.id/index. $\mathrm{php} / \mathrm{cp} / \mathrm{article} / \mathrm{view} / 7365$.

Nouri, J. (2016). The flipped classroom: for active, effective and increased learning especially for low achievers. International Journal of Educational Technology in Higher Education, 13(1), 1-10. https:// doi.org/10.1186/s41239-016-0032-z.

O'Neal, C., \& Pinder-Grover, T. (2005). How can you incorporate active learning into the classroom? Active learning techniques. Ann Arbor, MI: Center for Research on Learning and Teaching. https://crlt.umich. edu/.

Samal, A. L. (2018). Implementasi pendidikan karakter di sekolah dan perguruan tinggi melalui pembelajaran aktif. [Implementation of character education in schools and colleges through active learning]. Jurnal Ilmia Iqra', 11(1), 1-22. https://doi.org/10.30984/jii.v11i1.576.

Shen, H. H., \& Xu, W. (2015). Active learning: qualitative inquiries into vocabulary instruction in Chinese 12 classrooms. Foreign Language Annals, 48(1), 82-99. https://doi.org/10.1111/flan.12137.

Slavin, R. E., Hurley, E. A., \& Chamberlain, A. (2003). Cooperative learning and achievement: Theory and research. In I. B. Weiner (Ed.). Handbook of Psychology. Hoboken, NJ: John Wiley \& Son. 177198. https://doi.org/10.1002/0471264385. wei0709.

Swiderski, S. M. (2011). Transforming principles into practice: Using cognitive active learning strategies in the high school classroom. The Clearing House a Journal of Educational Strategies Issues and Ideas, 84(6), 239-243. https://doi.org $\underline{10.1080 / 00098655.2011 .590549 .}$.

Suswandari, M., Siswandari, S., Sunardi, S., \& Gunarhadi, G. (2020). Social skills for primary school students: Needs analysis to implement the scientific approach based curriculum. Journal of Social Studies Education Research, 11(1), 153-162. https://jsser.org/index.php/jsser/article/ view/1980.

Taraban, R., Box, C., Myers, R., Pollard, R., \& Bowen, C. W. (2007). Effects of activelearning experiences on achievement, attitudes, and behaviors in high school Biology. Journal of Research in Science Teaching, 44(7), 960-979. https://doi. org/10.1002/tea.20183.

Tomkin, J. H., Beilstein, S. O., Morphew, J. W., \& Herman, G. L. (2019). Evidence that communities of practice are associated with active learning in large STEM lectures. International Journal of STEM Education, 6(1), 1-15. https://doi. org/10.1186/s40594-018-0154-Z.

Unin, N., \& Bearing, P. (2016). Brainstorming as a way to approach student-centered learning in the ESL classroom. Procedia - Social and Behavioral Sciences, 224, 605-612. https://doi.org/10.1016/j. sbspro.2016.05.450.

Vizeshfar, F., Zare, M., \& Keshtkaran, Z. (2019). Role-play versus lecture methods in community health volunteers. Nurse Education Today, 79, 175-179. https:// doi.org/10.1016/j.nedt.2019.05.028.

Vygotsky, L. S., Davydovm V. V., \& Rober, S. (1977). Educational psychology. New York, N.Y: CRC Press.

Wu, W.-C. V., Marek, M., \& Chen, N. S. (2013). Assessing cultural awareness and linguistic competency of EFL learners in a CMC-based active learning context. System, 41(3), 515-528. https://doi. org/10.1016/j.system.2013.05.004. 